\title{
THE PRECARIOUS FRESHWATER RESOURCES OF SABLE ISLAND, NOVA SCOTIA, CANADA: OCCURRENCE AND MANAGEMENT CONSIDERATIONS
}

\author{
T.W. HENNIGAR ${ }^{1^{*}}$ AND G.W. KENNEDY* \\ ${ }^{1} 395$ Ridge Road, Wolfville, NS, B4P 2RI
}

\begin{abstract}
This paper presents an overview of the hydrogeology and the freshwater resources of Sable Island, Nova Scotia. The role of the sand deposits, morphology and dynamics of the dune structures and systems, precipitation, and tidal influences are discussed. The distribution, quality, and importance of both surface water and groundwater resources of the island are also presented.

Fresh groundwater on the Island occurs in an unconfined sand lens aquifer. Studies to date on the hydrogeology of the island have shown highly variable rates of precipitation, both seasonally and annually, which in combination with the influence of shifting dune structures contribute to a dynamic freshwater/saltwater balance. Infiltration rates into the permeable aquifer system are greater than precipitation rates, precluding surface water flow.

The chemical quality of water in the freshwater lens aquifer is generally good and meets the Guidelines for Canadian Drinking Water Quality. The aquifer is vulnerable to surface contamination, however, due to its shallow, unconfined nature, and any water supply wells are highly likely to be classified as being 'under the direct influence of surface water' (GUDI). Under these conditions a multi-barrier source water protection plan is considered essential for managing future public drinking water supplies on the Island. Recommendations for future studies, including long-term monitoring of water level trends, are provided to support the sustainable use of groundwater on the Sable Island.
\end{abstract}

\section{INTRODUCTION}

Sable Island was designated a National Park Reserve in 2013, and management of the Park's ecological integrity requires an understanding of prevailing environmental conditions, including freshwater resources. The objective of this paper is to provide an overview of the geological setting and freshwater resources of Sable Island, describing

* Authors to whom correspondence should be addressed: terry.hennigar@gmail.com and gavin.kennedy@novascotia.ca 
the factors controlling the distribution, movement and vulnerability of groundwater on the island, and outlining some of the considerations for protecting and managing the island's potable fresh water resources.

Given that the study of hydrogeology is still in its infancy relative to many other scientific disciplines, and the remote location of Sable Island, there have been limited opportunities to develop our understanding of the Island's aquifer system. Most oceanic islands in the literature subject to hydrogeologic characterization are volcanic, karst, or coral as a geologic framework. Sable Island, located 200 $\mathrm{km}$ off the coast of Nova Scotia, Canada, (Fig 1) is unusual because its geologic framework consists of a thick deposit of loose, unconsolidated sand, which is very uniform in texture, size, and mineral composition. The sands of Sable Island can be considered a container in which groundwater is stored temporarily as it flows towards the Atlantic Ocean. The island's shape, regional isolation, tidal effects, and low relief contribute to its sensitivity in terms of supplies of freshwater resources.

An initial study of the Sable Island sand aquifer system was conducted in the early 1970's (Hennigar 1976), and represents an early hydrogeological investigation of oceanic island sand aquifers in Nova Scotia. The study involved a number of hydrogeological assessment techniques included drilling exploratory test holes (disturbed samples only, no coring), water level and quality monitoring, geophysics, and hydraulic testing. The two main areas of study during the 1970s water resources investigation (Hennigar 1976) are shown in Fig 2. The upper portion of the figure is the area between the West Light

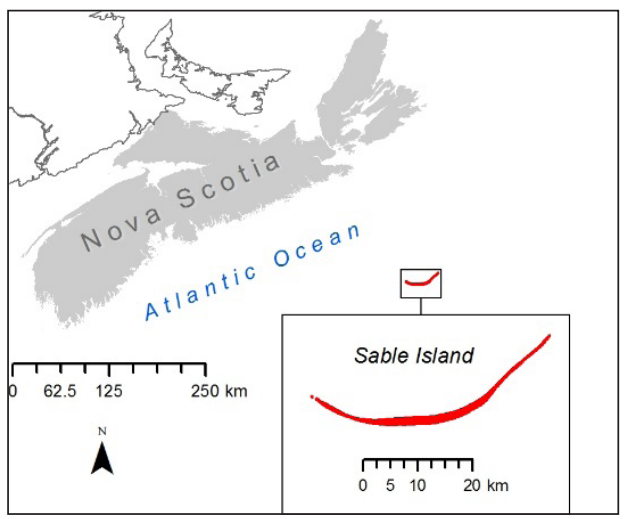

Fig 1 Location of Sable Island. 


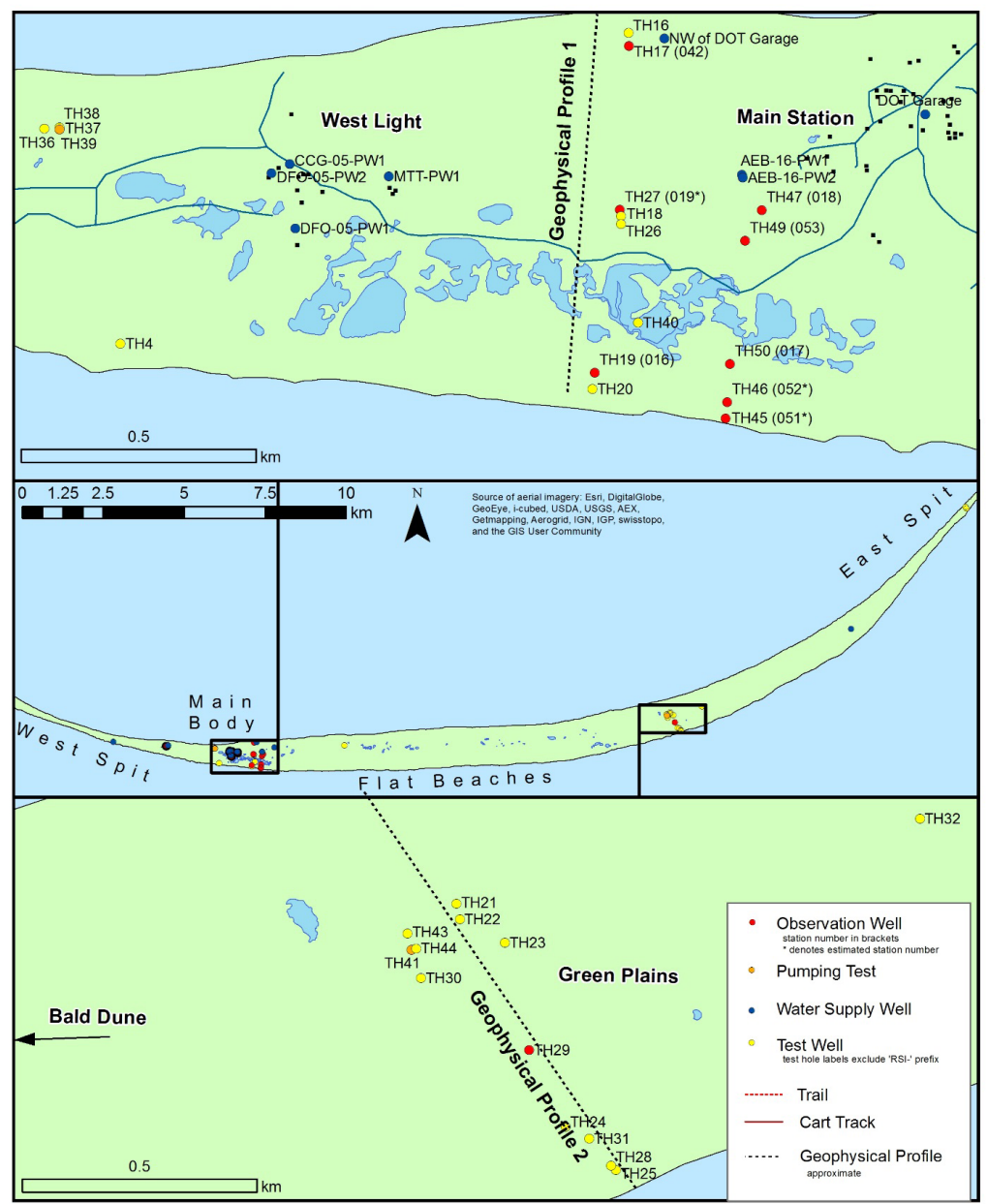

Fig 2 Two areas of the Island with Groundwater Investigations in 1976 (After Kennedy et al. 2014).

and the Main Station. The lower portion of the figure is in the Green Plains area, which is located in the east central portion of the island. This area of the island has no record of previous development.

\section{THE SANDS OF SABLE ISLAND}

Sable Island is the upper portion of the Sable Bank, a large area of sand deposits located $200 \mathrm{~km}$ south of Nova Scotia. It is near the 
confluence of waters from the Gulf of St. Lawrence from the north and the Gulf Stream from the southwest, near the edge of the Scotian Shelf (Fig 1). Seismic and bore hole records from on-shore oil and gas exploration indicate the glaciated platform in and around Sable Island is underlain in some areas by over 500 meters of unconsolidated Quaternary-Age sand deposits (King 2001). Samples collected during drilling to depths of 60 meters during the 1970s (Hennigar 1976) showed no significant stratification, except for occasional layers of organic and /or peat material. The sand material was quite homogeneous consisting of mainly quartz grains, with minor feldspars, and heavy metals. The sand grain sizes varied from $0.008 \mathrm{~mm}$ to $0.18 \mathrm{~mm}$ in diameter and were sub-rounded to rounded in shape. Although the sands on the island are considered eolian (wind-blown, transported, and deposited) they have been transported considerable distance from their original source. The origin of the source of on-shore and off-shore sands is most likely outwash materials from the ablating Laurentide Ice Sheet, occurring in the area around 10,000 to 20,000 years ago (Hennigar 1976). The label 'shifting sands of Sable Island' apply to the surface dune systems, the beaches, spits, and the offshore sand bars and banks which extend several kilometers offshore in all directions from the island.

\section{HYDROLOGIC CYCLE}

The hydrologic cycle on Sable Island differs from the typical components of the hydrologic cycle because there are no streams or overland flow on the island. All of the other components of the hydrologic cycle, however, are present, including precipitation; infiltration; evaporation, transpiration, and groundwater discharge to the ocean.

Assuming that runoff and groundwater use are negligible on Sable Island, the general formulation of the hydrological budget for the island can therefore be expressed as follows (Kennedy et al. 2014):

$$
\begin{aligned}
& \Delta \mathrm{S}=\mathrm{P}-\mathrm{ET}-\mathrm{Q}_{\mathrm{s}} \text { where } \\
& \Delta \mathrm{S}=\text { change in groundwater and surface water storage } \\
& \mathrm{P}=\text { precipitation } \\
& \mathrm{ET}=\text { evapotranspiration } \\
& \mathrm{Q}_{\mathrm{S}}=\text { subsurface discharge to the ocean }
\end{aligned}
$$




\section{Precipitation}

Precipitation is the source of all freshwater to the ponds and groundwater. Long-term records of precipitation on Sable Island indicate increasing annual rates of precipitation between 1941 and 2010. Records of precipitation from 1941 to 1970 indicate a 30 year mean annual rate of $1,270 \mathrm{~mm}$, whereas data from 1981 to 2010 indicate a 30 year mean annual precipitation of $1,459 \mathrm{~mm}$ (Fig 3). These data show an increase in the average annual precipitation rate of $189 \mathrm{~mm}$, or $15 \%$, when the two 30 year periods are compared. Similarly, Kennedy et al. (2014) reported an increasing trend in annual precipitation between 1970 and 1991 of $12 \mathrm{~mm} / \mathrm{yr}$.

Comparison of total precipitation recorded in 1971 to mean monthly precipitation recorded over a 30 year period from 1941 to 1970 shows that rainfall during the summer of 1971 was below normal from June to October (Fig 3). During this five month period in 1971 rainfall was only $50 \%$ of normal seasonal values recorded on the island. A review of annual precipitation records over the past 40 years indicated a range of $995.5 \mathrm{~mm}$ (2007) to $1810.1 \mathrm{~mm}$ (1986) (Fig 4), which also highlights a significant variability of precipitation on the island.

The effect of drought periods on Sable Island and the resulting impact on the freshwater lens under the island are not well known. Water level data, however, recorded in three observation wells during

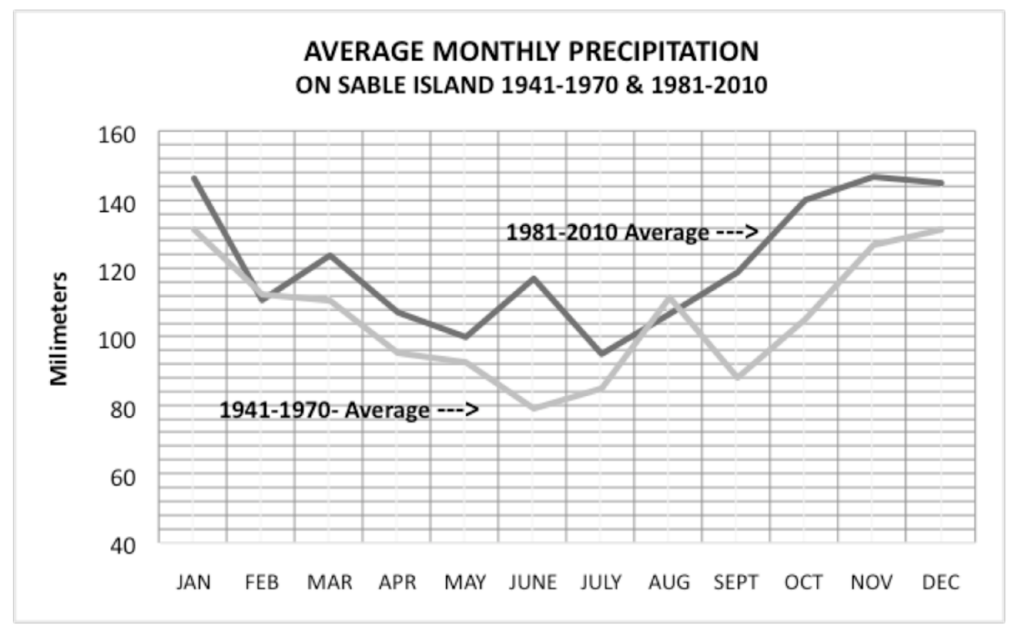

Fig 330 Year normal precipitation patterns on Sable Island. 


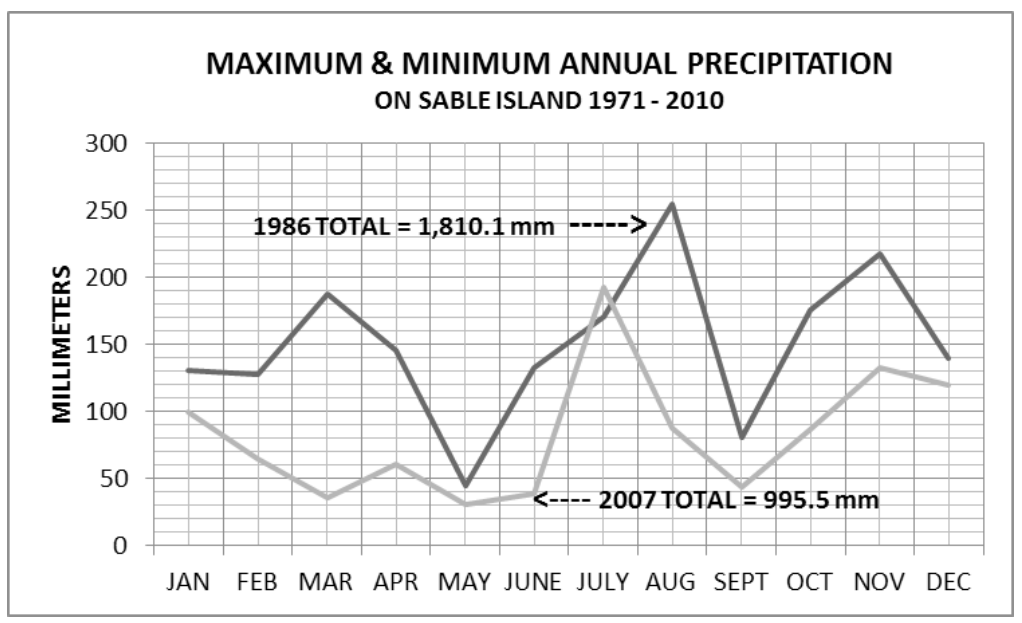

Fig 4 Variations in monthly precipitation over the period 1971-2011.

the period 1971 to 1990 show lower water levels in the groundwater reservoir during the drier summer months (Kennedy et al. 2014).

\section{Infiltration}

Infiltration is the portion of precipitation that falls to earth and percolates downward through the soils and recharges the groundwater reservoir, which underlies Sable Island as a freshwater lens at various depths below surface. The very high rates of infiltration on the island are evident from the lack of streams and overland flow. The infiltration capacity of the sand deposits on Sable Island was assessed at a number of sites during the summer of 1972 using a Guelph Permeameter. These data showed infiltration rates exceeded 1,200 mm per hour (Hennigar 1976), which is approximately four times greater than the maximum monthly precipitation rate of $250 \mathrm{~mm}$ per month recorded in August of 1986 (Fig 4). The high infiltration capacity of the sands explains why there is no stream or overland water flow on Sable Island. Groundwater levels were found to respond within 2 hours (Hennigar 1976) following the onset of precipitation. In comparison, groundwater level responses in mainland aquifers may be days, or weeks, depending on the soil types, depth to water table, stratigraphy in the unsaturated zone, and confining/semi-confining aquifer characteristics. 


\section{Evapotranspiration}

Evapotranspiration (ET) is the portion of water lost from an area as a result of the combined effects of evaporation from ponds and other surface water sources, and transpiration from trees, plants, grasses, and other forms of vegetation. The estimate of evapotranspiration during the 1970's (Hennigar 1976) was based entirely on the mathematical model POTEV using the moisture budget technique. The published value was the first estimate of evapotranspiration on Sable Island, and was comparable to values obtained during various groundwater investigations in other parts of mainland Nova Scotia at that time. ET water losses on Sable Island were estimated to represent $38 \%$ of precipitation. During the period 1965 to 1975 values ranging from $30 \%$ to $40 \%$ were reported in studies on the mainland where stream flow data was used as part of the water budget calculation. Mean annual evapotranspiration in the Annapolis-Cornwallis Valley, Nova Scotia was estimated to be about $40 \%$ of precipitation using the Thornthwaite method and modelled available soil moisture values (Rivard et al. 2007).

\section{SURFACE WATER CHARACTERISTICS}

Surface water on Sable Island is found in shallow ponds located in the low-lying areas of the island. The surfaces of ponds in the lowlying areas are believed to be, in most cases, expressions of the water table which fluctuates in response to precipitation events and tidal cycles. Water levels in ponds at higher elevations are believed to be recent precipitation perched above the groundwater table.

Land classification using aerial photography and LiDAR techniques by the Applied Geomatics Research Group (flown in August of 2009) identified approximately 70 ponds of various sizes on Sable Island (AGRG 2011). These ponds were grouped into a number of systems located in low lying areas of the island and contain either fresh water or brackish water, depending on whether they receive seawater inputs from high tides and storm surges. A number of the shallower ponds are ephemeral/ seasonal and become dry during summers of low precipitation. Dry ponds occur when the water table falls below the pond bottom, or when evaporation from perched ponds exceeds storage from precipitation. In some cases dry ponds are likely to result from the effects of both the above losses of pond water. 
The 2009 mapping was conducted during a period of low groundwater levels which showed water only in the lowest depressions of the low-lying areas. The total water area was determined to be 21.8 hectares covering less than $1 \%$ of the island (AGRG 2011). Surface water mapping during periods of high groundwater levels would most likely show more and larger ponds covering a total greater area. It is interesting to note that the greatest number of ponds are located in the west central portion of the island (Fig 2), including two small ponds that developed on the newly formed grassy area of the West Spit. Over half of the ponds are located in the area between West Light and the Red Buoy, an area including the Main Station. There are no ponds located in the area east of the Bald Dune where dune elevations are also the highest on the island.

Based on the 2009 maps and cross-sections provided (AGRG 2011), it appears that many of the ponds are located in topographic low areas of one meter or less, most likely representing surface expression of the water table. However in some areas of the island the ponds appear to be located at elevations greater than one meter above sea level (e.g. Fig 5). The ponds and wetlands located at higher elevations suggest that the water level in these features is perched above the local water table, possibly due to the low permeability of the pond substrate. Such conditions are not uncommon in Nova Scotia, but are not well documented or understood.

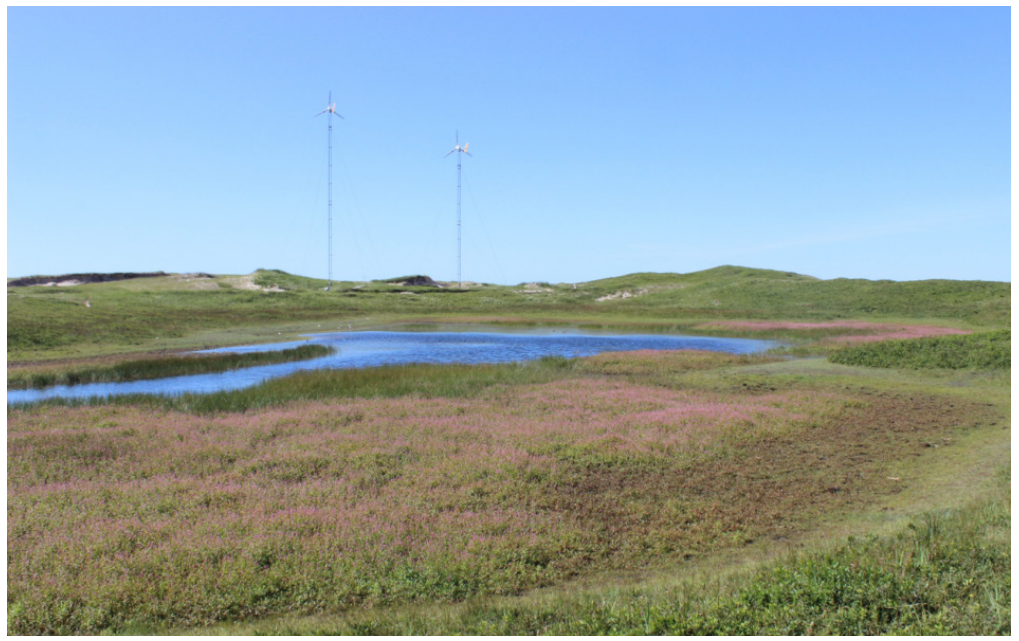

Fig 5 A fresh water pond protected by dunes at an elevation near mean sea level. 


\section{GROUNDWATER CHARACTERISTICS}

Groundwater became the focus of a freshwater study in 1971 when Mobil Oil approached the Nova Scotia Department of Mines (now part of Department of Natural Resources) inquiring about a supply of freshwater on Sable Island to support the on-island oil and gas exploratory drilling program. This request prompted an exploratory survey of the geology and water resources of the island. The resulting study of the groundwater resources included the drilling of 23 deep exploratory test holes for the collection of geological samples to understand the nature of the aquifer system in which groundwater occurs (Fig 2). Depths of these exploratory wells ranged from 15 to $60 \mathrm{~m}$, with the deepest well located near the center of the island. All of the wells were cased with steel casing with a one meter stainless steel screen installed at the bottom of the well to allow water sample collection from discrete depths. In addition, another 27 shallow screened wells were installed with either $50 \mathrm{~mm}$ diameter PVC or steel casing and one meter long stainless steel screens to depths ranging from 5 to $10 \mathrm{~m}$ below surface. All well heads were surveyed for elevation above mean sea level (asl) using established benchmarks installed by the Canadian Hydrographic Service in 1963.

A number of the test holes were selected for additional assessment including the installation of continuous water level monitoring instruments, the collection of water samples for chemical analyses, and the determination of hydraulic conductivity (Fig 2). Eight wells were equipped with instrumentation for monitoring water level fluctuations and operated on a part time basis for nearly 20 years before they were abandoned. A summary of water level data is presented in Table 1 . The range in water levels observed at the various observation wells varies from $0.22 \mathrm{~m}$ to $1.36 \mathrm{~m}$, which is enough variability for shallow ponds to appear 'dry' when the water level falls below the ground surface. Shallow ponds with perched water tables would be dominated by precipitation and evapotranspiration since they are at least partially isolated from regional shallow groundwater inflow and tend to occur at higher elevations, and are therefore more likely to become 'dry' during drought periods.

The upper surface of the unconfined aquifer is the water table. The thickness, or depth, of the fresh water lens, under static conditions, is a function of the density difference between fresh water and sea water as described by the Ghyben-Herzberg relation in a static environment. 
Table 1 Summary of water level data on Sable Island (after Kennedy et al. 2014 a, b).

\begin{tabular}{|c|c|c|c|c|c|c|c|}
\hline $\begin{array}{l}\text { Station } \\
\text { Number }\end{array}$ & Well ID & Easting $^{1}$ & Northing $^{1}$ & $\begin{array}{l}\text { Monitoring } \\
\text { Period }\end{array}$ & $\begin{array}{c}\text { Min. } \\
\text { Water } \\
\text { Level } \\
\left(\mathbf{m} \text { asl }{ }^{3}\right)\end{array}$ & $\begin{array}{l}\text { Max. } \\
\text { Water } \\
\text { Level } \\
(\mathrm{m} \text { asl) }\end{array}$ & $\begin{array}{c}\text { Max. } \\
\text { Range } \\
\text { (m) }\end{array}$ \\
\hline 042 & RSI-TH17 & 739676 & 4868933 & 1972 & -0.68 & -0.23 & 0.45 \\
\hline 016 & RSI-TH19 & 739603 & 4868237 & $1971-1990$ & -0.65 & 0.71 & 1.36 \\
\hline 0192 & RSI-TH27 & 739657 & 4868584 & 1971-1972 & $\begin{array}{c}\text { Not } \\
\text { assessed }\end{array}$ & $\begin{array}{c}\text { Not } \\
\text { assessed }\end{array}$ & - \\
\hline 0512 & RSI-TH45 & 739882 & 4868140 & 1972 & $\begin{array}{c}\text { Not } \\
\text { assessed }\end{array}$ & $\begin{array}{c}\text { Not } \\
\text { assessed }\end{array}$ & - \\
\hline 0522 & RSI-TH46 & 739886 & 4868174 & 1972 & $\begin{array}{c}\text { Not } \\
\text { assessed }\end{array}$ & $\begin{array}{c}\text { Not } \\
\text { assessed }\end{array}$ & - \\
\hline 018 & RSI-TH47 & 739959 & 4868583 & $1972-1974$ & -0.02 & 0.2 & 0.22 \\
\hline 053 & RSI-TH49 & 739924 & 4868518 & 1984-1990 & -0.17 & 0.54 & 0.71 \\
\hline 017 & RSI-TH50 & 739891 & 4868255 & $1975-1990$ & -0.51 & 0.67 & 1.18 \\
\hline
\end{tabular}

${ }^{1}$ All coordinates are expressed in NAD83 Zone 20.

${ }^{2}$ Station number predicted based on gaps in provincial numbering sequence ${ }^{3}$ asl: above mean sea level

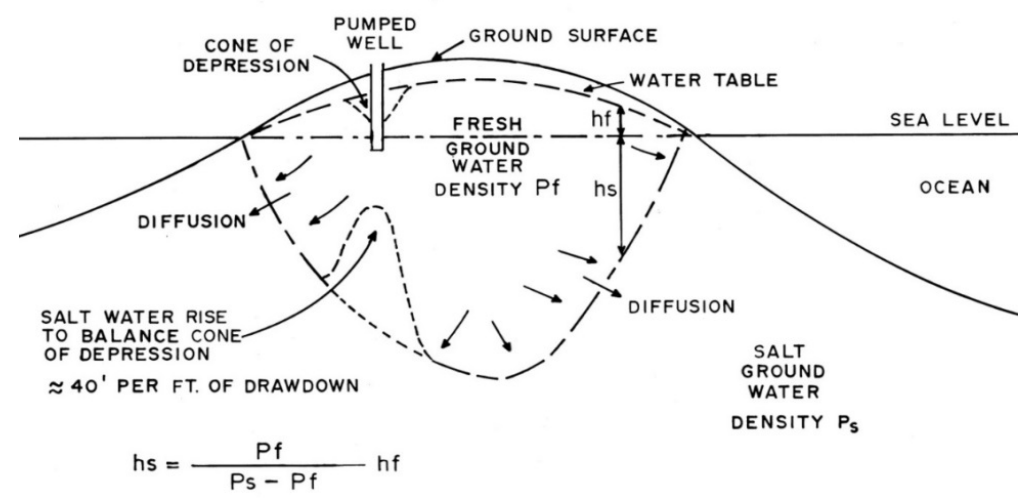

Fig 6 Typical cross-section of a freshwater lens under an island.

This density difference is typically a ratio of approximately forty to one. Fig 6 illustrates an idealized cross section of a fresh water lens under an island, and shows that when the fresh water level is lowered one meter by pumping, the salt water interface rises by 40 meters.

On Sable Island the elevation, above mean sea level, of the lens at the center of the island is approximately 1.2 meters, resulting in a depth of fresh water of approximately 36.6 meters. Conditions on Sable Island, however, are anything but static. Not only is the island's 
morphology changing at the surface, but the rates and timing of infiltration, water levels, and tidal effects are changing in the subsurface. The continuity of the freshwater lens along the island is not known, and is most likely changing with storm surges, seasonal supplies of recharge/ infiltration, sea-level rise, and changes in the morphology of the island due to sediment dynamics.

The freshwater lens profile, as interpreted in 1976 for the Green Plains area of the island (Fig 2), is a double-convex feature which pinches out near the north and south beaches (Fig 7). The freshwater lens in this area is protected from seawater intrusion by the North and South dunes systems. The upper surface of the lens is slightly higher in the center of the island with an approximate slope seaward of $0.1 \%$. For comparison purposes, groundwater level gradients on mainland Nova Scotia can be greater than $10 \%$ where the unconfined water table follows the land topography.

During a visit to the island in August 2013, it was observed that the south beach as shown in Fig 7 has been eroded inland by approximately $244 \mathrm{~m}$ (800 feet). It is interesting to note that erosion of the south beach was extensive enough to remove the dune feature through which test holes TH25 and TH28 were drilled in 1971. As documented in August 2013, the steel well casings of TH25 and TH28 are now on the beach and extend 4.9 meters above the ground surface (Hennigar 2013). A water level monitoring instrument was installed in test well TH29, and this well could not be found in August 2013. It is suspected that the sand, or a portion of the eroded sand from the

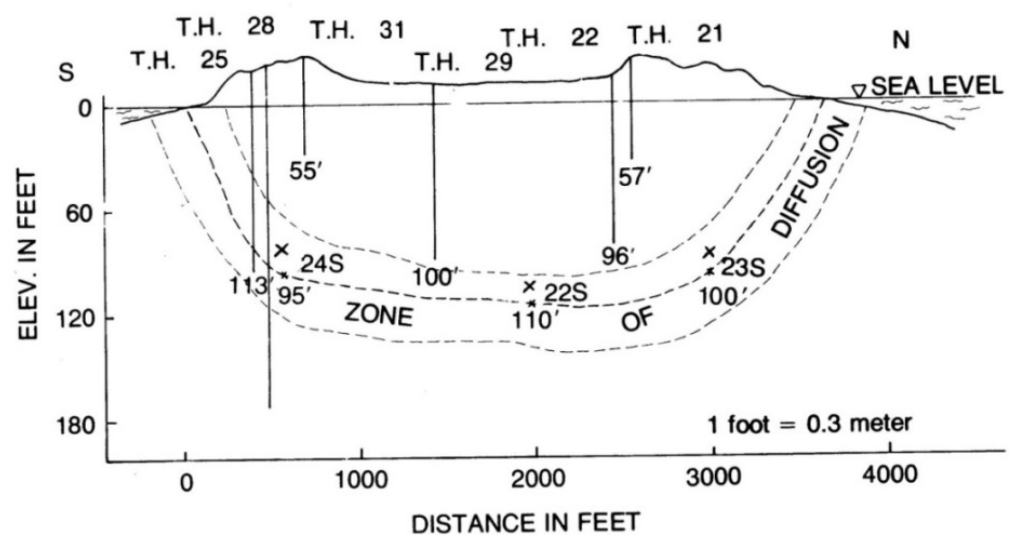

Fig 7 The freshwater lens under the Green Plains (After Hennigar 1976). 


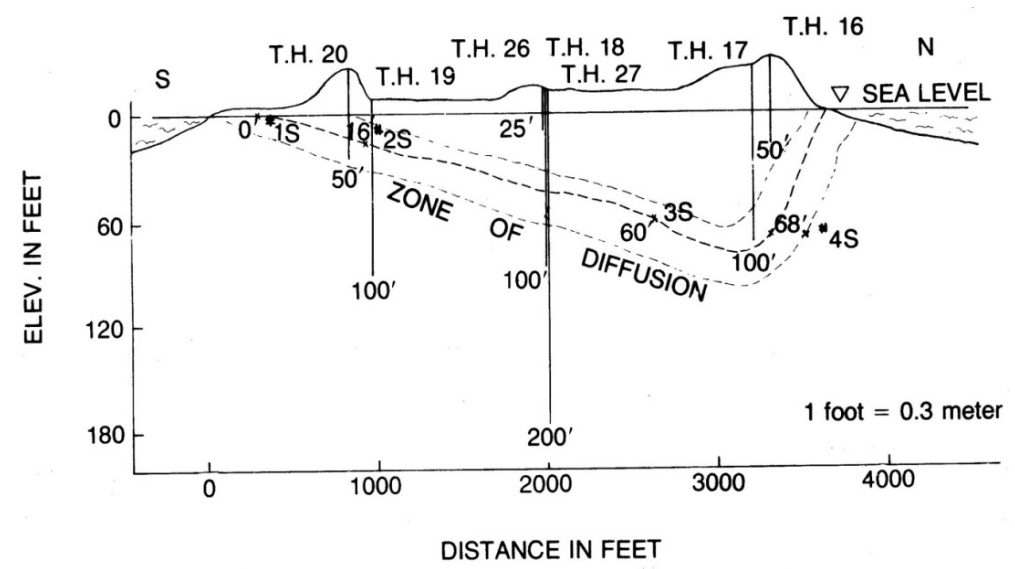

Fig 8 The freshwater lens under Sable Island west of the main station (After Hennigar 1976).

dune, was re-deposited in the vicinity of TH29 to a depth sufficient to bury the monitoring well and instrument shed.

With the loss of a large extent of the south beach and the south dune system, the freshwater lens under the Green Plains area now likely has a shape similar to the lens configuration interpreted along a transect west of the Main Station in 1976 (Fig 2, Fig 8). It is believed that the configuration of the lens in this area was influenced by seawater intrusion into the pond system in that area of the south beach, in addition to freshwater pumping for the Main Station water supply.

\section{Aquifer Properties}

Two pumping tests have been conducted on the Island and the results of these tests are summarized in Table 2. Hydraulic conductivity of the unconfined sand aquifer is estimated to be on the order of $1 \times 10^{-3} \mathrm{~m} / \mathrm{s}$ to $1 \times 10^{-2} \mathrm{~m} / \mathrm{s}$ based on the pumping test results. The interpreted transmissivities (447-462 $\mathrm{m}^{2} /$ day) were higher than the median value reported for Quaternary mainland sand and gravel aquifers (250 $\mathrm{m}^{2} /$ day) (Kennedy and Drage 2009). Using the interpreted transmissivity values and an available long-term drawdown of $1 \mathrm{~m}$, the long-term safe yield is estimated to be approximately $150 \mathrm{Lpm}$. It should be noted, however, that this yield exceeds the test pumping rate, and groundwater quality considerations (e.g. seawater intrusion) will be a critical factor in determining the safe pumping rate of any well sited on the island. 
Hennigar (1976) observed that where the thickness of the freshwater lens is at least $3 \mathrm{~m}$, the geometry is favourable (inland of barrier dune), and the well is a sufficient distance from the coast that the cone of drawdown will not intercept the lateral seawater-freshwater interface, groundwater supplies producing approximately $160 \mathrm{~m}^{3} / \mathrm{d}$ (110 Lpm) should be feasible.

Table 2 Summary of pumping tests

\begin{tabular}{lcc}
\hline & RSI-TH39 & RSI-TH41 \\
\hline Pumping Test ID & HAL-167 & HAL-168 \\
Easting $^{1}$ & 738462 & 752426 \\
Northing $^{1}$ & 4868755 & 4869773 \\
Well Depth ( m) & 3.9 & 4.2 \\
Casing Diameter (mm) & 38 & 38 \\
Screen Length (m) & 0.9 & 0.9 \\
Screen Size & 10 slot & 10 slot \\
Date & August 8,1972 & September 12,1972 \\
Test Duration (hrs) & 8 & 12 \\
Average Pumping Rate $\left(\mathrm{m}^{3} / \mathrm{d}\right)$ & 163.7 & 163.7 \\
Transmissivity (m $/ \mathrm{d})$ & 446.85 & 461.75 \\
Storativity & 0.05 & 0.03 \\
Long-Term Safe Yield $(\mathrm{Lpm})\left(\mathrm{Q}_{20}\right)^{2}$ & 148 & 153 \\
\hline
\end{tabular}

${ }^{1}$ All coordinates are expressed in NAD83 Zone 20.

${ }^{2}$ Long-term safe pumping rate for a well is calculated using the twenty-year safe well yield calculation (Farvolden 1959).

\section{GROUNDWATER AND SURFACE WATER CHEMISTRY}

The only readily available and safe drinking water on the island is found in the freshwater reservoir of groundwater underlying the dune systems. On Sable Island, pond water chemistry depends on the geologic and physiographic setting of the pond, and is associated with a variety of microorganisms and elevated salinity from tidal surges and sea spray, as recorded by Hennigar (1976) and other researchers in more recent studies (Freedman 2014).

The microbiology of surface water, which typically includes various types of bacteria, protozoa (Giardia, Cryptosporidium), viruses (120 types) has not been thoroughly investigated to our knowledge. The most common microbiological examination of drinking water sources includes the presence and/or absence of the fecal indicator organisms such as Escherichia coli bacteria, and total coliform bacteria. Sources of the microbiological contaminants in surface water ponds on Sable 
Island include the horses, birds, humans, and other warm blooded animals. At least one potential case of microbiological illness is documented by O'Hara (2014), when she and her sister mixed pond water and Jell-O powder, and, after drinking the mixture, became violently ill. Their illness may have been from microbiological organisms such as common parasites found in surface waters. Treating surface water sources to a safe level for human consumption requires considerable effort which is also costly and entails ongoing maintenance and operational demands which are often quite costly.

A review of groundwater chemistry data, for samples collected from the fresh water lens outside of the areas of potential environmental concern, indicate typically good quality water, with no exceedances of health based Canadian Drinking Water Quality Guideline (GCDWQ) limits (Health Canada 2014), with the exception of lead, which may be attributed to leaching of metal plumbing fixtures (Appendix A). Parameters of aesthetic concern include iron (geomean: $1157 \mu \mathrm{g} / \mathrm{L}$ ), manganese (geomean: $67 \mu \mathrm{g} / \mathrm{L}$ ) chloride (geomean: $72 \mathrm{mg} / \mathrm{L}$ ), and $\mathrm{pH}$ (median: 6.1). The chemistry of the fresh water lens has been described by Hennigar (1976), PW\&GS Canada (1996), Stantec (2010), and Kennedy et al. (2014 a, b) for several potable water supplies on the island.

The general chemistry of groundwater on the island is consistent with a shallow, unconfined groundwater-flow system in a coastal setting, and is generally described as low $\mathrm{pH}$, very soft, naturally aggressive, sodium-chloride-type water, with dilute to moderate concentrations of TDS (total dissolved solids) and a tendency for iron and manganese to exceed the GCDWQ aesthetic objectives (AO) (Health Canada 2014).

\section{GROUNDWATER MANAGEMENT}

\section{Groundwater Contamination}

The use of hydrocarbons as a fuel on Sable Island dates back to 1905. That was the year when the first wireless communication station was established, and gasoline was needed to run generators for electricity (Armstrong 1981, Martin 2015). It is also reported that navigation lights used oil for illumination and mercury to float the lights for easy rotation. The map provided in Armstrong (1981) also 
shows old and current light house locations and previous old lifeboat stations on the island.

The first targeted study related to subsurface contamination on the island was carried out during 1995 - 96 by Environmental Services, Public Works \& Government Services, Canada (PWGSC 1996). This investigation focused on the federal government departments with operations on the island at that time and included Phase I, II, and III environmental site assessments with the purpose of identifying and describing subsurface contamination associated with federal infrastructure and operations on Sable Island. Of the ten areas of potential environmental concerns identified, eight areas were found to contain petroleum hydrocarbons that exceed guidelines.

A subsequent study by Jacques Whitford - Stantec Limited (2009) also identified 10 areas of potential environmental concern based on the use, storage, leaks, and disposal of materials with a history of causing groundwater contamination. The focus of their study was on the portion of the island from the west light eastward to the Helicopter pad. The greatest impacts were associated with fuel tank storage and handling.

Although the federal sites on the island have been assessed for soil and water contamination, a number of other non-federal sites should also be investigated for potential sources of contamination including some of the sites of historical oil and gas exploration drilling, the crash site of an aircraft in 1944, and other non-federal sites.

\section{Protecting Drinking Water Supplies}

The federal-Provincial-Territorial Committee on Drinking Water in Canada has recommended a multi- barrier approach to protecting drinking water supplies, which was a key recommendation of the Walkerton Commission following the tragedy in Walkerton, Ontario where contamination from surface water containing E. coli bacteria resulted in the deaths of seven persons, and serious illness to another 2,300 in the town. The Province of Nova Scotia has adopted this approach for the management of public drinking water supply systems.

Public drinking water supplies are smaller than municipal supplies and are defined in Nova Scotia as a water supply system with at least 15 service connections or serves 25 or more people per day for at least 60 days per year. The owner of a public drinking water supply system is required to test, report and if necessary undertake corrective actions but they are not certified operators. 
This multi-barrier approach is summarized as follows:

1. Keeping the water clean. This is achieved by selecting the highest quality of water available and protecting it from contamination.

2. Making it safe. This is achieved by treatment to remove natural and man-made impurities and ensuring good system operations.

3. Proving it safe. This achieved by consistently testing water quality, monitoring, and taking swift corrective action when deficiencies are identified.

The multi-barrier approach is recognized in Nova Scotia as the best approach to providing safe drinking water to the public and this approach should be applied to any future water supply development on Sable Island. The province has a responsibility in a number of areas to support and provide guidance to both the owners and the operators of public water supply systems in exercising their due diligence to protect the public from drinking water contamination.

Protocols have been developed by the USEPA (1992) and modified by Nova Scotia Environment (2015), as well as other provinces, to determine the sensitivity of a groundwater supply to be impacted by surface water. The process for assessing the likelihood that microbial pathogens can travel from surface water to an aquifer supplying water to a well is referred to as a GUDI (Groundwater Under the Direct Influence) assessment. In Nova Scotia this process consists of three steps which require information on well location, hydrogeology, well construction, and ambient water quality. From our understanding of the construction of water supply wells on the island, it is highly likely that potable wells would be considered as GUDI. This hypothesis is primarily based on the nature of the unconfined aquifer system providing the water, and typical well construction, with less than 12 meters of casing below ground surface.

\section{SUMMARY AND CONCLUSIONS}

The following are the main points of our paper:

1. Precipitation, the source of freshwater on Sable Island is highly variable on a seasonal basis and annually over the past 70 years.

2. The fresh groundwater supply under the island occurs in an unconfined aquifer system bounded by the north and south beaches. 
3. The maximum water table head above sea level is approximately $1.5 \mathrm{~m}$ above mean sea level in the center portion of the island.

4. Infiltration rates of the sands are higher than precipitation rates which result in no surface runoff as streamflow or overland runoff.

5. Approximately $40 \%$ of the precipitation is lost due to evapotranspiration while the remaining $60 \%$ is available to recharge the freshwater lens.

6. The thickness of the freshwater lens, as determined by resistivity surveys and water chemical analyses, varies from approximately 0 meters near the beaches, to $40 \mathrm{~m}$ near the central portion of the island.

7. Groundwater fluctuations recorded over the past 40 years reveal water table level changes from $0.22 \mathrm{~m}$ to $1.36 \mathrm{~m}$.

8. It is suspected that a water level change of $1.36 \mathrm{~m}$ is greater than the depth of some of the ponds and results in 'dry' pond conditions during drought periods.

9. Groundwater quality is generally good and meets the maximum acceptable concentrations of the Guidelines for Canadian Drinking Water Quality.

10. The soils and groundwater have been found to be contaminated with petroleum hydrocarbons and some metals in areas of extensive historic and current long term human activity.

11. Special attention and a multi barrier approach will be required when developing, operating, managing, and protecting future public drinking water supplies on Sable Island.

12. Water supplies from shallow supply wells on the island are highly likely to be classified as under the direct influence of surface water (GUDI).

\section{RECOMMENDATIONS}

The following is recommended to improve the understanding of the freshwater resources of Sable Island and to assist Parks Canada with the responsible development of groundwater on the island in support of a future eco-tourism program:

1. Develop a long-term water level and groundwater chemistry monitoring network consisting of a series of dedicated observation wells at appropriate locations. Monitoring should also be 
conducted to determine evaporation and transpiration rates of pond and dune areas on the island.

2. Continue to identify and assess the main areas of potential groundwater contamination on the island and conduct appropriate risk management/ remediation activities.

3. Develop a density dependent groundwater flow model of the groundwater system to locate suitable target areas for groundwater supply development,

4. Develop well head protection plans for public drinking water supply sources.

5. Identify ponds across the island that may be perched using high resolution elevation mapping techniques and field assessment of pond bottom benthic material permeability.

6. Assess groundwater-surface water interactions to determine the influence of pond benthic material on surface water levels, the susceptibility of ponds to seawater intrusion from tidal flooding, and their reliability as water supplies for horses and other wildlife on the island.

\section{REFERENCES}

Applied Geomatics Research Group. (2011). Sable Island, Nova Scotia, 2009 Topography and Land Cover Atlas, 122 pp.

Armstrong, B. (1981). Sable Island. Doubleday Canada Limited, Toronto, ON. 210 pp.

Driscoll, F.G. (1986). Groundwater and Wells, Second edition. Johnson Division, St. Paul, MN.

Freedman, B. (Ed). (2014). Ecological and Biodiversity Assessment of Sable Island. Report to Parks Canada. Halifax, N.S. 400 pp.

Health Canada. (2014). Guidelines for Canadian Drinking Water Quality. www.hc-sc.gc.ca/.

Hennigar, T.W. (1976). Water Resources and Environmental Geology of Sable Island, Nova Scotia, Department of the Environment, Report No. 76-1, 56 pp.

Hennigar, T.W. (2013). Groundwater Monitoring Report, Sable Island, Report to Parks Canada, Halifax, N.S., 32 pp.

Jacques Whitford Stantec Limited. (2009). Final Groundwater Monitoring Program, Environment Canada Meteorological Services of Canada, Sable Island, Halifax County, Nova Scotia, DFRP \#07610, Project No. 1044685, Report to Public Works and Government Services Canada, 532 pp. 
Kennedy, G.W. \& Drage, J.M. (2009). Hydrogeologic characterization of Nova Scotia's groundwater regions. In Proceedings, GeoHalifax2009, the 62nd Canadian Geotechnical Conference and the 10th Joint CGS/IAHCNC Groundwater Conference, International Association of HydrologistsCanadian National Chapter, Halifax, Nova Scotia, p. 1230-1240; http:// novascotia.ca/natr/meb/data/pubs/cs/cs_me_2009-004.pdf.

Kennedy, G. W., Drage, J., \& Hennigar, T.W. (2014a). Groundwater Resources of Sable Island, Nova Scotia. Open File Report ME 2014-001, Nova Scotia Department of Natural Resources. http://novascotia.ca/natr/ meb/pdf/14ofr01 .asp.

Kennedy, G.W., Drage, J., \& Hennigar, T.W. (2014b). Groundwater Resources of Sable Island (Chapter 7). In Freedman, B. (Ed), An Ecological and Bioidiversity Assessment of Sable Island. Report to Parks Canada, Halifax, NS. 400 pp.

King, E.L. (2001). A glacial origin for Sable Island: ice and sea-level fluctuations from seismic stratigraphy on Sable Island Bank, Scotian Shelf, offshore Nova Scotia, In Current Research 2001-D19, Geological Survey of Canada, Natural Resources Canada, 13 pp.http://ftp2.cits.rncan.gc.ca/ pub/geott/ess_pubs/212/212173/cr_2001_d19.pdf.

Martin-Boutillier, J. (2015). Return to Sable. AuthorHouse, 459 pp.

Nova Scotia Environment. (2015). Protocol for Determining Groundwater under the Direct Influence of Surface Water. Internal document, NSDE, Halifax, NS.

O'Hara, S., \& O’Hara, M. (2014). Our Sable Island Home. Pottersfield Press, $174 \mathrm{pp}$.

Public Works \& Government Services Canada. (1996). Phase I,II, and III Environmental Sites Assessments, Government of Canada Operations and Facilities, Sable Island, Nova Scotia, Project Nos. 615988 \& 616417. Rivard, C., et al. (2007). Canadian Groundwater Inventory: Hydrogeological Atlas of the Annapolis Valley, Nova Scotia, GSC Open File 5541.

Stantec Consulting Ltd. (2010). Final Monitoring \& Phase II ESA, Environment Canada, Meteorological Services of Canada, Sable Island, Nova Scotia. DFRP \#07610, Project No. 1056158, Report to Public Works \& Government Services Canada, 623 pp.

U.S. Environmental Protection Agency (U.S.EPA). (1992). Consensus Method for Determining Groundwater under the Direct Influence of Surface Water Using Microscopic Particulate Analysis (MPA). U.S. EPA910/9-92-029. October 1992. 


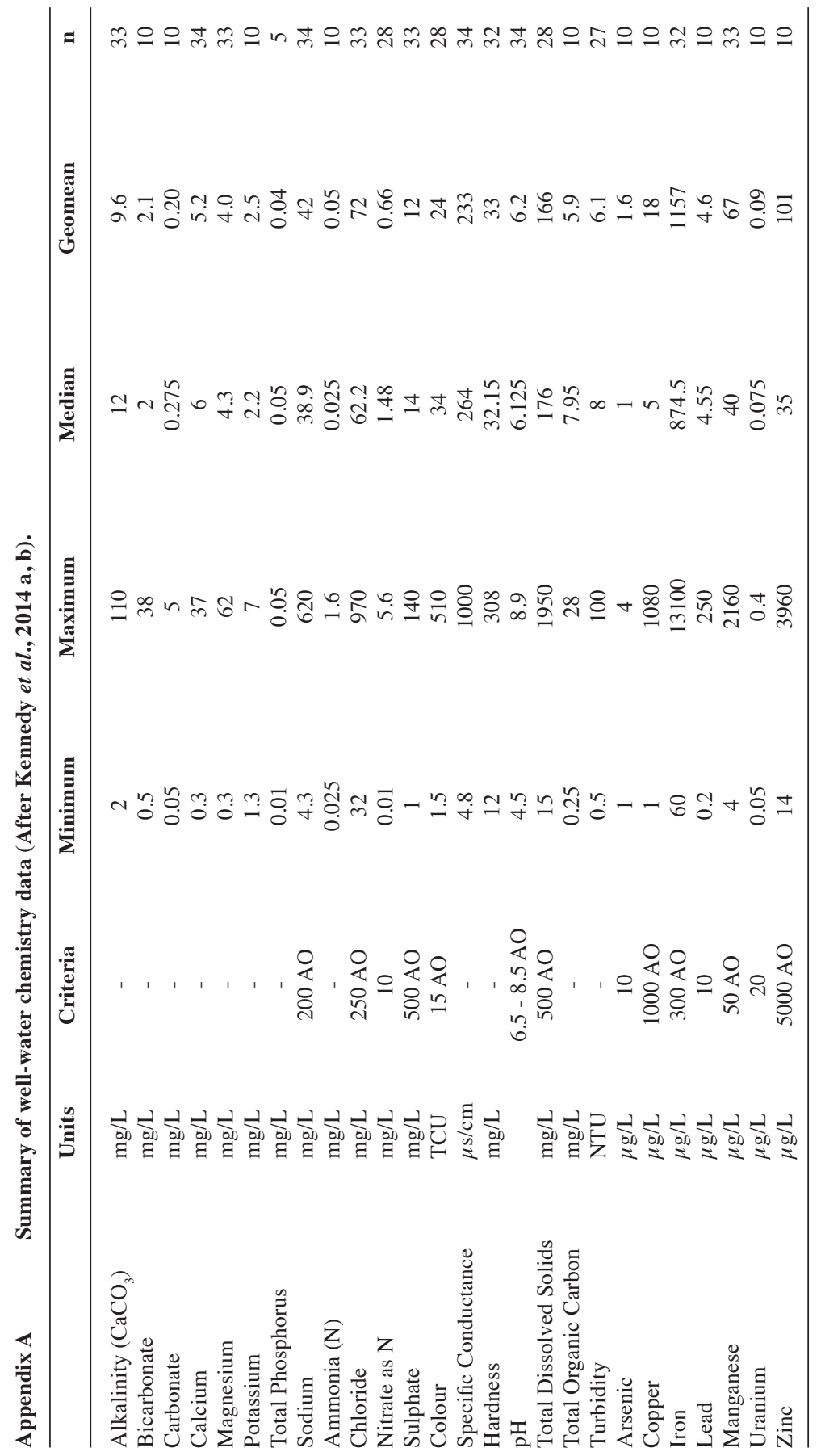

